\title{
Multivariate Analysis and Heavy Metals Pollution Evaluation in Yellow River Surface Sediments
}

\author{
Jun Ren ${ }^{1,2 *}$, Zhen Shang ${ }^{1}$, Ling Tao ${ }^{1,2}$, Xia Wang ${ }^{1}$ \\ 'School of Environmental and Municipal Engineering, Lanzhou Jiaotong University, Lanzhou 730070, P. R. China \\ ${ }^{2}$ Engineering Research Center for Cold and Arid Regions, Water Resource Comprehensive Utilization, \\ Ministry of Education, Lanzhou 730070, P. R. China
}

Received: 23 November 2014

Accepted: 18 January 2015

\begin{abstract}
The concentrations of heavy metals in 21 samples collected from surface sediments from the Qinghai section of the Yellow were investigated in order to evaluate their distribution and pollution levels. The total concentrations showed wide variations with $\mathrm{Cu} 11.86 \sim 57.02 \mathrm{mg} / \mathrm{kg}$, Fe $17236.67 \sim 41340.00 \mathrm{mg} / \mathrm{kg}$, Mn $431.93 \sim 877.27 \mathrm{mg} / \mathrm{kg}$, Ni $14.58 \sim 86.11 \mathrm{mg} / \mathrm{kg}, \mathrm{Zn} 67.18 \sim 149.00 \mathrm{mg} / \mathrm{kg}, \mathrm{Cr} 87.84 \sim 169.70 \mathrm{mg} / \mathrm{kg}, \mathrm{Pb}$ $1.21 \sim 20.69 \mathrm{mg} / \mathrm{kg}$, and $\mathrm{Cd} 0.27 \sim 1.43 \mathrm{mg} / \mathrm{kg}$. The mean values of the heavy metal contents were arranged in the following decreasing order: $\mathrm{Fe}>\mathrm{Mn}>\mathrm{Cr}>\mathrm{Zn}>\mathrm{Ni}>\mathrm{Cu}>\mathrm{Pb}>\mathrm{Cd}$. The correlation between $\mathrm{Cu}, \mathrm{Fe}$, and $\mathrm{Zn}$ concentrations was significantly positive. These heavy metals had common sources, mutual dependence, and identical behavior during transport. However, there was no significant correlation among some of these metals, indicating different anthropogenic and natural sources. PCA extracted three components with eigenvalues explaining $76.259 \%$ of the total variance. $\mathrm{Fe}, \mathrm{Mn}$, and $\mathrm{Zn}$ had a common natural origin controlled by the first component. $\mathrm{Cu}, \mathrm{Ni}$, and $\mathrm{Cd}$ could originate anthropogenic sources controlled by the second component. The higher values of geo-accumulation index, enrichment factor, and pollution load index of $\mathrm{Cr}$ in the Qinghai section were attributed principally to anthropogenic activities such as industrial effluents, vehicular emissions, and terrigenous influx from the river. $\mathrm{Zn}$ appeared to pose no risk at all of the sites of the system. In total, the pollution class from the Qinghai section of the river is $0-1$, belonging to the unpolluted to moderately polluted degree.
\end{abstract}

Keywords: river, metal, sediments, assessment

\section{Introduction}

Sediments act as both carriers and sinks for contaminants in aquatic environments [1], which causes pollutants to play an important role and provides a reasonable history of pollution in the river [2]. Metals are regarded as serious pollutants of aquatic ecosystems because of their environmental persistence, toxicity, and ability to be incorporated

*e-mail: renjun@mail.lzjtu.cn into food chains [3-5]. When the environmental conditions of the water lying over the sediments changes, heavy metals in the sediments could be released into the water, thereby deteriorating its quality $[6,7]$. Since they can pose potential threats to ecosystems and human health, the distribution and pollution levels of heavy metals in sediments has been extensively studied [7-18].

Heavy metals have long been continuously introduced into river, estuarine, and coastal sediments. Heavy metals were added to an aquatic system by natural or anthro- 
pogenic sources. Natural sources mainly included weathering of soil and rock, erosion, forest fires, and volcanic eruptions, whereas urban and industrial discharge, mining and refining, and agricultural drainage caused by anthropogenic activities also discharged into the rivers [19-24]. Knowledge of the distribution and concentrations of the heavy metals in the sediments could help detect the source of pollution in the aquatic systems. The assessment of the potential ecological risk of heavy metal contamination was proposed as a diagnostic tool for water pollution control purposes as a result of the increasing content of heavy metals in sediments and their subsequent release into water, which could threaten ecological heath. So far the enrichment factor, geo-accumulation index, the potential ecological risk index, and sediment quality guidelines have been extensively introduced to assess pollution for heavy metals [25-32]. The risk assessment of heavy metals would provide certain theory support for risk management [3].

The Yellow is located at north latitude $32^{\circ} \sim 42^{\circ}$, east longitude $96^{\circ} \sim 119^{\circ}$. It is the second longest river in China, originating in Qinghai Province and meandering through Qinghai, Sichuan, Gansu, Ningxia, Inner Mongolia, Shanxi, Shaanxi, Henan, and Shandong Provinces, inflowing lastly from Shandong Province into the Bohai Sea. Total length is $5,464 \mathrm{~km}$, and the basin area is $795,000 \mathrm{~km}^{2}$ [33]. The Yellow was the biggest sand transformation river in the world, and as a result of serious pollution the water-sand system has representative effects on the adsorption of pollutants, especially heavy metals. The Yellow has had great influence on human civilization [34]. In recent years, this study investigated the distribution and contamination level of heavy metals in surface sediments from the Qinghai section of the Yellow, and potential risks of heavy metals to the environment were assessed using the geo-accumulation index, enrichment factor, and pollution load index.

\section{Material and Methods}

\section{Study Area}

Qinghai Province is located in north latitude $31^{\circ} \sim 39^{\circ}$, east longitude $89^{\circ} \sim 103^{\circ}$ in western China. At about the main stream of the Yellow above Minghe country, tributaries of the Datong River and Huangshui basin were the Yellow upstream in Qinghai Province, locating mainly in the southeast part of the province, adjacent to the Qilian Mountains and water system in Hexi corridor, Bayankala Mountain, and the Yangtze River water system, inland water system. The Yellow basin in Qinghai section is $176,000 \mathrm{~m}^{2}$ and total length is $1,983 \mathrm{~km}$.

The Yellow originated from the Qinghai-Tibet Plateau, a river source area that is upstream from Maduo country. The relative height difference was 100 200 $\mathrm{m}$ in the river source area, and height above sea level was 4,200 4,600 m. Upstream of the Yellow in Qinghai, that section gave way to a plateau continental climate. In addition to the part belonging to semi-arid areas, the other areas belong to a semi-humid region. Annual precipitation was 250 800 mm
Table 1. Geological locations of sampling points from the Qinghai section upstream of the Yellow River.

\begin{tabular}{|c|c|c|}
\hline Sample point & Latitude & Longitude \\
\hline QH1 & $35^{\circ} 01^{\prime} 33^{\prime \prime}$ & $96^{\circ} 50^{\prime} 56^{\prime \prime}$ \\
\hline $\mathrm{QH} 2$ & $35^{\circ} 04^{\prime} 58^{\prime \prime}$ & $97^{\circ} 55^{\prime} 28^{\prime \prime}$ \\
\hline QH3 & $35^{\circ} 00^{\prime} 47^{\prime \prime}$ & $98^{\circ} 04^{\prime} 04^{\prime \prime}$ \\
\hline QH4 & $34^{\circ} 53^{\prime} 06^{\prime \prime}$ & $98^{\circ} 10^{\prime} 19^{\prime \prime}$ \\
\hline QH5 & $34^{\circ} 49^{\prime} 43^{\prime \prime}$ & $98^{\circ} 21^{\prime} 09^{\prime \prime}$ \\
\hline QH6 & $33^{\circ} 46^{\prime} 07^{\prime \prime}$ & $98^{\circ} 39^{\prime} 23^{\prime \prime}$ \\
\hline QH7 & $33^{\circ} 48^{\prime} 39^{\prime \prime}$ & $98^{\circ} 43^{\prime} 41^{\prime \prime}$ \\
\hline QH8 & $33^{\circ} 46^{\prime} 14^{\prime \prime}$ & $101^{\circ} 10^{\prime} 38^{\prime \prime}$ \\
\hline QH9 & $33^{\circ} 27^{\prime} 22^{\prime \prime}$ & $102^{\circ} 15^{\prime} 11^{\prime \prime}$ \\
\hline QH10 & $33^{\circ} 51^{\prime} 21^{\prime \prime}$ & $102^{\circ} 12^{\prime} 43^{\prime \prime}$ \\
\hline QH11 & $34^{\circ} 41^{\prime} 12^{\prime \prime}$ & $100^{\circ} 38^{\prime} 39^{\prime \prime}$ \\
\hline QH12 & $34^{\circ} 08^{\prime} 29^{\prime \prime}$ & $100^{\circ} 13^{\prime} 17^{\prime \prime}$ \\
\hline QH13 & $35^{\circ} 43^{\prime} 55^{\prime \prime}$ & $100^{\circ} 27^{\prime} 19^{\prime \prime}$ \\
\hline QH14 & $36^{\circ} 05^{\prime} 00^{\prime \prime}$ & $101^{\circ} 29^{\prime} 39^{\prime \prime}$ \\
\hline QH15 & $36^{\circ} 06^{\prime} 59^{\prime \prime}$ & $101^{\circ} 32^{\prime} 44^{\prime \prime}$ \\
\hline QH16 & $36^{\circ} 03^{\prime} 55^{\prime \prime}$ & $101^{\circ} 56^{\prime} 09^{\prime \prime}$ \\
\hline QH17 & $36^{\circ} 01^{\prime} 49^{\prime \prime}$ & $101^{\circ} 58^{\prime} 44^{\prime \prime}$ \\
\hline QH18 & $35^{\circ} 58^{\prime} 13^{\prime \prime}$ & $102^{\circ} 02^{\prime} 11^{\prime \prime}$ \\
\hline QH19 & $35^{\circ} 56^{\prime} 21^{\prime \prime}$ & $102^{\circ} 02^{\prime} 49^{\prime \prime}$ \\
\hline QH20 & $35^{\circ} 53^{\prime} 17^{\prime \prime}$ & $103^{\circ} 04^{\prime} 02^{\prime \prime}$ \\
\hline QH21 & $35^{\circ} 52^{\prime} 37^{\prime \prime}$ & $102^{\circ} 25^{\prime} 05^{\prime \prime}$ \\
\hline
\end{tabular}

in the area, runoff form mainly had ice and snow meltwater and precipitation recharge, water regional distribution was not in balance. Annual average temperature was $5-8^{\circ} \mathrm{C}$. Some heavy metals originated from industrial discharge, mining and refining, agricultural drainage, and municipal sewage caused by anthropogenic activities [34].

\section{Sample Collection and Analytical Methods}

Surface sediment samples were randomly collected from 21 different sampling sites according to the trend of the river and accessibility in the Qinghai section of Yellow in June 2013 (Table 1). The upper 0 5 cm depth of surface sediment and controlling soil samples in the river bank was taken. They were then placed into polyethylene bags and returned to the laboratory. Care was taken to avoid any contamination. Sediment samples were then frozen at $4^{\circ} \mathrm{C}$ prior to analysis. Station locations were obtained using GPS. All these samples were air dried at room temperature and sieved through a $2 \mathrm{~mm}$ nylon sieve to remove coarse debris. The sediments were then ground with a pestle and mortar until all particles passed a $0.074 \mathrm{~mm}$ nylon sieve for analysis. 
For the total heavy metal content analysis, all of the samples for the chemical analysis were powdered in Teflon tubes. About $0.5 \mathrm{~g}$ fractions of powdered sediment were digested to a mixture of $10 \mathrm{ml} \mathrm{HCl}(\rho=1.19 \mathrm{~g} / \mathrm{ml}), 10 \mathrm{ml}$ $\mathrm{HNO}_{3}(\rho=1.42 \mathrm{~g} / \mathrm{ml}), 10 \mathrm{ml} \mathrm{HF}(\rho=1.49 \mathrm{~g} / \mathrm{ml})$, and $10 \mathrm{ml}$ $\mathrm{HClO}_{4}(\rho=1.68 \mathrm{~g} / \mathrm{ml})$ at $180^{\circ} \mathrm{C}$ in a microwave oven.

The solution of the digested sample was analyzed by inductively coupled plasma-atomic emission spectrometry (ICP-AES, IRIS Intrepid II XSP, Thermo Electron Corporation, USA) for $\mathrm{Cu}, \mathrm{Fe}, \mathrm{Mn}, \mathrm{Ni}, \mathrm{Zn}, \mathrm{Cr}, \mathrm{Pb}$, and $\mathrm{Cd}$.

\section{Assessment of Sediment Contamination}

The geo-accumulation index $\left(I_{\text {geo }}\right)$ was used to assess heavy metal accumulation in sediments to measure the degree of metal pollution in aquatic sediment studies [26].

$$
I_{\text {geo }}=\log _{2}[C n /(1.5 \times B n)]
$$

...where $C_{n}$ was the measured concentration of a heavy metal in surface sediments, $B_{n}$ was the geochemical background value in average shale of element $n$, and 1.5 was the background matrix correction due to terrigenous effects [23].

Enrichment factor $(E F)$ was employed to assess the degree of contamination and to understand the distribution of the elements of anthropogenic origin from sites by individual elements in sediments. Fe was chosen as the normalizing element while determining $E F$ values since in wetlands it is mainly supplied from sediments and is one of the most widely used reference elements.

$$
E F=\left(C_{n} / F e\right)_{\text {sample }} /\left(C_{n} / F e\right)_{\text {background }}
$$

...where $C_{n}$ is the content ration of element $n$. The background value was that of average shale. An element qualifies as a reference one if it was of low occurrence variability and was present in the environment in trace amounts.
Elements that were naturally derived had an $E F$ value of near unity, while elements of anthropogenic origin have $E F$ values of several orders of magnitude.

The pollution load index $(P L I)$ for each site was evaluated by heavy metal contamination:

$$
\begin{gathered}
C F_{i}=\frac{C_{i}}{C_{0 i}} \\
P L I=\sqrt[n]{C F_{1} \times C F_{2} \times C F_{3} \times \cdots \times C F_{n}}
\end{gathered}
$$

...where $n$ is the number of metals and $C F$ was the contamination factor. $C_{i}$ was metal $i$ concentration in sediments; $C_{0 i}$ was background value of the metal $i$. The degree of contamination could be determinate by pollution load index.

\section{Results and Discussion}

\section{Distribution of Heavy Metals}

The total concentrations showed wide variations with $\mathrm{Cu} 11.86 \sim 57.02 \mathrm{mg} / \mathrm{kg}, \mathrm{Fe} 17236.67 \sim 41340.00 \mathrm{mg} / \mathrm{kg}, \mathrm{Mn}$ $431.93 \sim 877.27 \mathrm{mg} / \mathrm{kg}$, Ni $14.58 \sim 86.11 \mathrm{mg} / \mathrm{kg}, \mathrm{Zn}$ $67.18 \sim 149.00 \mathrm{mg} / \mathrm{kg}, \quad \mathrm{Cr} \quad 87.84 \sim 169.70 \mathrm{mg} / \mathrm{kg}, \quad \mathrm{Pb}$ $1.21 \sim 20.69 \mathrm{mg} / \mathrm{kg}$, and Cd $0.27 \sim 1.43 \mathrm{mg} / \mathrm{kg}$. The mean values of $\mathrm{Cu}, \mathrm{Fe}, \mathrm{Mn}, \mathrm{Ni}, \mathrm{Zn}, \mathrm{Cr}, \mathrm{Pb}$, and $\mathrm{Cd}$ are $24.03 \mathrm{mg} / \mathrm{kg}$, $30424.57 \mathrm{mg} / \mathrm{kg}, 669.84 \mathrm{mg} / \mathrm{kg}, 37.55 \mathrm{mg} / \mathrm{kg}, 96.23 \mathrm{mg} / \mathrm{kg}$, $122.21 \mathrm{mg} / \mathrm{kg}, 9.73 \mathrm{mg} / \mathrm{kg}$, and $0.75 \mathrm{mg} / \mathrm{kg}$. The mean values of the heavy metal contents are arranged in the following decreasing order: $\mathrm{Fe}>\mathrm{Mn}>\mathrm{Cr}>\mathrm{Zn}>\mathrm{Ni}>\mathrm{Cu}>\mathrm{Pb}>\mathrm{Cd}$ for sediments from the Yellow. These showed that Fe and $\mathrm{Mn}$ presented higher levels in Yellow sediments, whereas $\mathrm{Cd}$ and $\mathrm{Pb}$ represented the lowest values (Table 2).

In this study, controlling soil samples in the riverbank for the Qinghai section upstream of the Yellow are selected as the background value. The mean values of all the heavy metal concentrations besides $\mathrm{Zn}$ and $\mathrm{Cd}$ for Yellow sediments are higher than background value for the Qinghai section. The average $\mathrm{Cu}, \mathrm{Fe}, \mathrm{Mn}, \mathrm{Ni}, \mathrm{Zn}, \mathrm{Cr}, \mathrm{Pb}$, and $\mathrm{Cd}$ con-

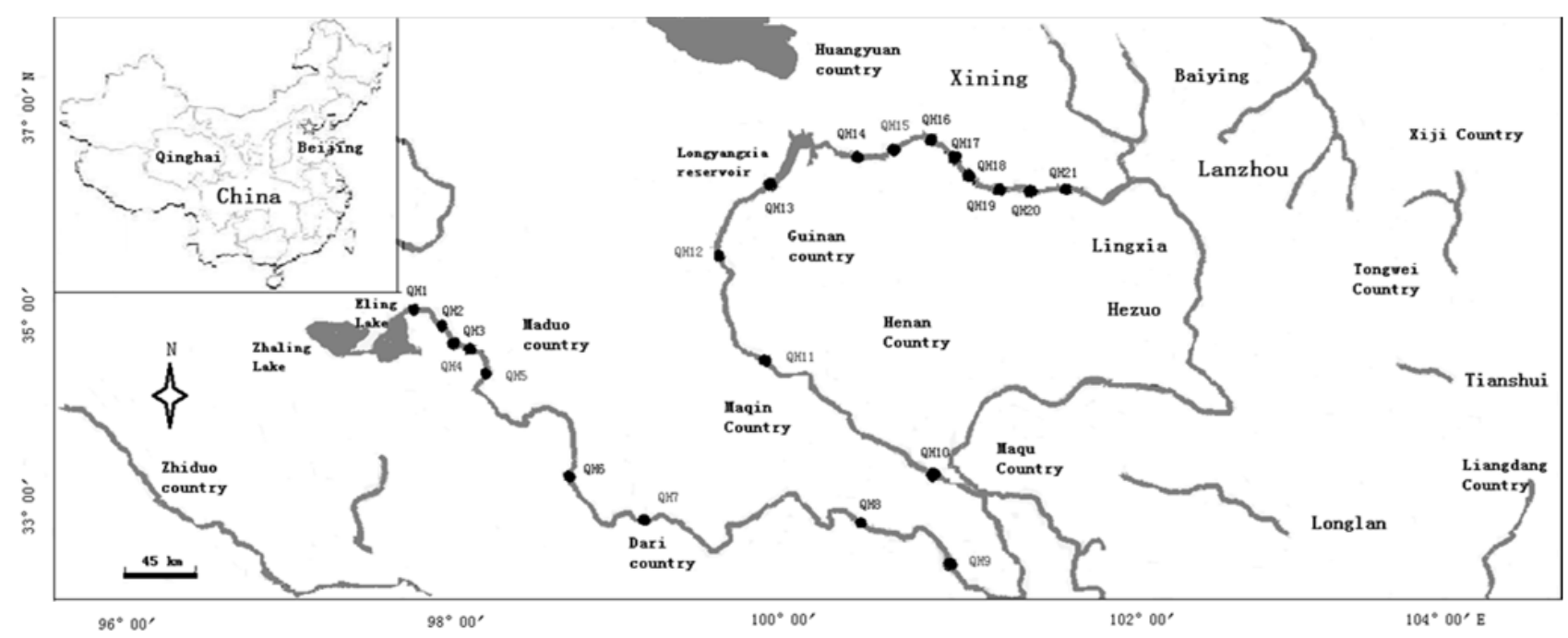

Fig. 1. Distribution of sampling sites from the Qinghai section upstream of the Yellow River. 
Table 2. Distribution of heavy metals in surface sediments from the Qinghai section upstream of the Yellow River.

\begin{tabular}{|c|c|c|c|c|c|c|c|c|}
\hline Sample point & $\mathrm{Cu}$ & $\mathrm{Fe}$ & $\mathrm{Mn}$ & $\mathrm{Ni}$ & $\mathrm{Zn}$ & $\mathrm{Cr}$ & $\mathrm{Pb}$ & $\mathrm{Cd}$ \\
\hline QH1 & 24.02 & 32215.40 & 715.60 & 21.03 & 92.51 & 103.22 & 8.21 & 1.27 \\
\hline QH2 & 24.41 & 36736.67 & 797.87 & 21.23 & 103.15 & 128.40 & 10.10 & 1.43 \\
\hline QH3 & 28.19 & 31770.00 & 613.03 & 53.05 & 86.59 & 102.27 & 14.87 & 0.62 \\
\hline QH4 & 27.04 & 28520.00 & 734.50 & 32.21 & 87.60 & 108.25 & 2.43 & 0.36 \\
\hline QH5 & 24.92 & 33660.00 & 772.37 & 45.43 & 102.35 & 155.00 & 11.44 & 0.66 \\
\hline QH6 & 25.99 & 29666.67 & 592.27 & 38.50 & 99.78 & 120.60 & 8.92 & 1.16 \\
\hline QH7 & 19.38 & 31363.33 & 561.60 & 14.58 & 106.88 & 123.36 & 9.22 & 0.71 \\
\hline QH8 & 15.02 & 32102.00 & 751.36 & 15.20 & 92.66 & 123.21 & 9.88 & 0.33 \\
\hline QH9 & 12.31 & 30040.03 & 498.57 & 16.89 & 78.96 & 134.02 & 9.13 & 0.46 \\
\hline QH10 & 13.06 & 20201.21 & 539.56 & 21.32 & 88.53 & 124.90 & 11.23 & 0.32 \\
\hline QH11 & 11.86 & 20637.33 & 431.93 & 48.71 & 67.18 & 96.34 & 8.50 & 0.79 \\
\hline QH12 & 15.35 & 25321.00 & 503.00 & 34.32 & 82.65 & 89.68 & 5.15 & 0.27 \\
\hline QH13 & 17.88 & 27530.00 & 574.20 & 20.38 & 96.91 & 87.84 & 1.21 & 0.96 \\
\hline QH14 & 28.01 & 32192.33 & 751.50 & 42.73 & 104.61 & 112.69 & 14.03 & 1.33 \\
\hline QH15 & 24.80 & 30926.67 & 685.80 & 43.26 & 97.85 & 110.00 & 6.66 & 0.56 \\
\hline QH16 & 30.98 & 32203.33 & 798.03 & 86.11 & 92.74 & 130.33 & 2.98 & 1.23 \\
\hline QH17 & 21.82 & 38080.00 & 877.27 & 47.14 & 101.72 & 169.70 & 20.69 & 0.51 \\
\hline QH18 & 57.02 & 17236.67 & 456.17 & 44.24 & 75.26 & 145.03 & 14.16 & 1.06 \\
\hline QH19 & 21.98 & 36260.00 & 874.17 & 31.44 & 109.37 & 142.27 & 15.68 & 0.32 \\
\hline QH20 & 34.38 & 41340.00 & 848.37 & 58.38 & 149.00 & 149.73 & 12.18 & 0.55 \\
\hline QH21 & 26.18 & 30913.33 & 689.37 & 52.40 & 104.59 & 109.47 & 7.65 & 0.85 \\
\hline Maximum & 57.02 & 41340.00 & 877.27 & 86.11 & 149.00 & 169.70 & 20.69 & 1.43 \\
\hline Minimum & 11.86 & 17236.67 & 431.93 & 14.58 & 67.18 & 87.84 & 1.21 & 0.27 \\
\hline Mean & 24.03 & 30424.57 & 669.84 & 37.55 & 96.23 & 122.21 & 9.73 & 0.75 \\
\hline Standard deviation & 9.82 & 5876.27 & 139.05 & 17.70 & 16.39 & 21.83 & 4.70 & 0.37 \\
\hline Variation coefficient & 0.41 & 0.19 & 0.21 & 0.47 & 0.17 & 0.18 & 0.48 & 0.50 \\
\hline Background value & 15.89 & 23761.02 & 531.72 & 32.03 & 102.31 & 53.96 & 9.60 & 0.81 \\
\hline
\end{tabular}

centrations for Yellow sediments are 1.51, 1.28, 1.26, 1.17, $0.94,2.26,1.01$, and 0.93 times the background value for the Qinghai section, which implies that the Yellow sediments have been unpolluted or slightly polluted by $\mathrm{Zn}$ and $\mathrm{Cd}$, and then have been seriously polluted by $\mathrm{Cu}$ and $\mathrm{Cr}$. The standard deviation of the heavy metal contents for the Qinghai section upstream of the Yellow are arranged in the following decreasing order: $\mathrm{Fe}>\mathrm{Mn}>\mathrm{Cr}>\mathrm{Ni}>\mathrm{Zn}>\mathrm{Cu}>\mathrm{Pb}>\mathrm{Cd}$. The variation coefficients were arranged in the following decreasing order: $\mathrm{Cd}>\mathrm{Pb}>\mathrm{Ni}>\mathrm{Cu}>\mathrm{Mn}>\mathrm{Fe}>\mathrm{Cr}>\mathrm{Zn}$ (Table 2). If the variation coefficient of a heavy metal was much smaller, the metals could have less pollution in Yellow surface sediment [34].

\section{Correlation Analyses}

The concentration data of metals in the Yellow sediments were subjected to the simple linear regression analysis to examine the possible correlation among different metals $[9,12,24]$. The significant positive correlation among contents of $\mathrm{Cu}, \mathrm{Fe}$ and $\mathrm{Zn}$ concentrations was shown (Table 3). High correlation coefficient between different metals means common sources, mutual dependence, and identical behavior during transport. The heavy metals were mainly of natural origin due to weathering and erosion [2]. The absence of strong correlation among other metals suggests that the concentrations of these metals were not controlled 
Table 3. Correlations matrix for the heavy metals in surface sediments from the Qinghai section upstream of the Yellow River.

\begin{tabular}{|c|c|c|c|c|c|c|c|}
\hline Metal & $\mathrm{Cu}$ & $\mathrm{Fe}$ & $\mathrm{Mn}$ & $\mathrm{Ni}$ & $\mathrm{Zn}$ & $\mathrm{Cr}$ & $\mathrm{Pb}$ \\
\hline $\mathrm{Fe}$ & -0.04 & & & & & & \\
\hline $\mathrm{Mn}$ & 0.12 & $0.85^{*}$ & & & & & \\
\hline $\mathrm{Ni}$ & $0.46^{*}$ & 0.13 & 0.26 & & & & \\
\hline $\mathrm{Zn}$ & 0.16 & $0.77^{*}$ & $0.68^{*}$ & 0.15 & & & \\
\hline $\mathrm{Cr}$ & 0.33 & 0.42 & $0.49^{*}$ & 0.19 & 0.40 & & \\
\hline $\mathrm{Pb}$ & 0.21 & 0.27 & 0.28 & 0.05 & 0.21 & $0.65^{*}$ & \\
\hline $\mathrm{Cd}$ & 0.40 & 0.04 & 0.04 & 0.20 & 0.02 & -0.11 & -0.10 \\
\hline
\end{tabular}

*Significant correlations are marked with $(\mathrm{P}<0.05)$

Table 4. Principal compoment analysis of heavy metals in sediments from the Qinghai section upstream of the Yellow River.

\begin{tabular}{|c|c|c|c|}
\hline Heavy metal & Factor 1 & Factor 2 & Factor 3 \\
\hline $\mathrm{Cu}$ & 0.343 & 0.805 & 0.181 \\
\hline $\mathrm{Fe}$ & 0.841 & -0.312 & -0.347 \\
\hline $\mathrm{Mn}$ & 0.869 & -0.159 & -0.266 \\
\hline $\mathrm{Ni}$ & 0.361 & 0.625 & -0.090 \\
\hline $\mathrm{Zn}$ & 0.799 & -0.173 & -0.314 \\
\hline $\mathrm{Cr}$ & 0.738 & 0.012 & 0.529 \\
\hline $\mathrm{Pb}$ & 0.549 & -0.037 & 0.696 \\
\hline $\mathrm{Cd}$ & 0.072 & 0.667 & -0.413 \\
\hline Eigenvalues & 3.198 & 1.637 & 1.265 \\
\hline Variance (\%) & 39.980 & 20.460 & 15.818 \\
\hline $\begin{array}{c}\text { Acumulated } \\
\text { variance (\%) }\end{array}$ & 39.980 & 60.440 & 76.259 \\
\hline
\end{tabular}

by a single factor, but a combination of geochemical support phases and their mixed associations [3]. The results in this study indicated that most examined metals didn't have common sources and that they could originate from various sources, and their behavior during transport may be varied. These metals were not associated with each other, and they might have different anthropogenic as well as natural sources [20].

\section{Principal Component Analysis}

Principal component analysis (PCA) was applied to assess the origin of metals in sediments. PCA extracted three components with eigenvalues explaining $76.259 \%$ of the total variance (Table 4). The three significant statistical components provide a basis for determining the areas influenced by the sedimentological and geochemical variations of the data set. The first component accounted for $39.980 \%$ of the total variance with high positive loadings of $\mathrm{Fe}$ (0.841), Mn (0.869), Zn (0.799), and Cr (0.738). Their combination in this component suggested a natural origin of these elements. Component 2 accounted for $20.460 \%$ of the total variance for $\mathrm{Cu}(0.805), \mathrm{Ni}(0.625)$, and $\mathrm{Cd}(0.667)-$ these metals could have originated from anthropogenic sources. Component 3 accounted for $15.818 \%$ of the total variance for $\mathrm{Pb}$ (0.696), which suggests that these meals may originate from anthropogenic sources. Cd could originate from anthropogenic sources. $\mathrm{Pb}$ had less loading to components 1 and 2; the source and distribution of $\mathrm{Pb}$ could be affected by natural geological background and human activity.

\section{Assessment of Heavy Metals Pollution}

Metal pollution could be assessed with respect to world surface rock averages or the widely used average shale with reference to the degree of contamination $[12,14]$. The source of pollution was therefore determined through the normalization of geoaccumulation values to the reference element. The degree of pollution in sediments could be assessed by determining the enrichment factor and indices such as the pollution load index and geo-accumulation index [11]. The calculated results of $I_{\text {geo }}$ indicated that only $\mathrm{Cr}(0.57)$ could be considered as from unpolluted to moderately polluted at some of the study stations. All other metals showed an unpolluted situation for other stations (Table 5). This was on the basis of the mean $I_{g e o}$ values of metals in the following order: $\mathrm{Cr}>\mathrm{Cu}>\mathrm{Fe}>\mathrm{Mn}>\mathrm{Ni}>\mathrm{Zn}>\mathrm{Pb}>\mathrm{Cd}$. Totality, the pollution class from the Qinghai section upstream of the Yellow was $0 \sim 1$ (unpolluted to moderately polluted; Table 5).

All the sediments samples are enriched with eight heavy metals $(E F<2)$, which belong to unpolluted to slightly polluted. The average metal $E F$ in sediments was in the order of $\mathrm{Cr}>\mathrm{Cu}>\mathrm{Fe}>\mathrm{Mn}>\mathrm{Ni}>\mathrm{Pb}>\mathrm{Zn}>\mathrm{Cd}$. Average $E F$ of $\mathrm{Zn}$ (0.73), $\mathrm{Pb}(0.79)$, and $\mathrm{Cd}(0.72)$ showed background levels. Average $E F$ of Fe (1.00), Mn (0.98), and Ni (0.92) had a value close to 1 , which could indicate some crustal origin for these metals. The average $E F$ of $\mathrm{Cu}(1.18)$ and $\mathrm{Cr}$ (1.77) were much higher, which belongs to slightly polluted (Table 5). The results indicate a metal source other than lithogenic debris [21].

According to the rank partition of pollution load index, the pollution class of the whole Qinghai section of the 
Table 5. Geo-accumulation index $\left(I_{\text {geo }}\right)$, Enrichment factor $(E F)$, and Pollution load index (PLI) of heavy metals in sediments from Qinghai section upstream of the Yellow River.

\begin{tabular}{|c|c|c|c|c|c|c|c|c|c|}
\hline Sample & $\mathrm{Cu}$ & $\mathrm{Fe}$ & $\mathrm{Mn}$ & $\mathrm{Ni}$ & $\mathrm{Zn}$ & $\mathrm{Cr}$ & $\mathrm{Pb}$ & $\mathrm{Cd}$ & $P L I$ (class) \\
\hline QH1 & 0.01 & -0.15 & -0.16 & -1.19 & -0.73 & 0.35 & -0.81 & 0.06 & 1.20 (I) \\
\hline QH2 & 0.03 & 0.04 & 0.00 & -1.18 & -0.57 & 0.67 & -0.51 & 0.24 & 1.34 (I) \\
\hline QH3 & 0.24 & -0.17 & -0.38 & 0.14 & -0.83 & 0.34 & 0.05 & -0.97 & 1.31 (I) \\
\hline QH4 & 0.18 & -0.32 & -0.12 & -0.58 & -0.81 & 0.42 & -2.57 & -1.75 & $0.93(0)$ \\
\hline QH5 & 0.06 & -0.08 & -0.05 & -0.08 & -0.58 & 0.94 & -0.33 & -0.88 & 1.37 (I) \\
\hline QH6 & 0.12 & -0.26 & -0.43 & -0.32 & -0.62 & 0.58 & -0.69 & -0.07 & 1.30 (I) \\
\hline QH7 & -0.30 & -0.18 & -0.51 & -1.72 & -0.52 & 0.61 & -0.64 & -0.78 & 1.06 (I) \\
\hline QH8 & -0.67 & -0.15 & -0.09 & -1.66 & -0.73 & 0.61 & -0.54 & -1.88 & $0.96(0)$ \\
\hline QH9 & -0.95 & -0.25 & -0.68 & -1.51 & -0.96 & 0.73 & -0.66 & -1.40 & $0.92(0)$ \\
\hline QH10 & -0.87 & -0.82 & -0.56 & -1.17 & -0.79 & 0.63 & -0.36 & -1.92 & $0.90(0)$ \\
\hline QH11 & -1.01 & -0.79 & -0.88 & 0.02 & -1.19 & 0.25 & -0.76 & -0.62 & $0.97(0)$ \\
\hline QH12 & -0.63 & -0.49 & -0.67 & -0.49 & -0.89 & 0.15 & -1.48 & -2.17 & $0.84(0)$ \\
\hline QH13 & -0.41 & -0.37 & -0.47 & -1.24 & -0.66 & 0.12 & -3.57 & -0.34 & $0.82(0)$ \\
\hline QH14 & 0.23 & -0.15 & -0.09 & -0.17 & -0.55 & 0.48 & -0.04 & 0.13 & 1.48 (I) \\
\hline QH15 & 0.06 & -0.20 & -0.22 & -0.15 & -0.65 & 0.44 & -1.11 & -1.12 & 1.16 (I) \\
\hline QH16 & 0.38 & -0.15 & 0.00 & 0.84 & -0.73 & 0.69 & -2.27 & 0.02 & 1.35 (I) \\
\hline QH17 & -0.13 & 0.10 & 0.14 & -0.03 & -0.59 & 1.07 & 0.52 & -1.25 & 1.48 (I) \\
\hline QH18 & 1.26 & -1.05 & -0.81 & -0.12 & -1.03 & 0.84 & -0.02 & -0.20 & 1.36 (I) \\
\hline QH19 & -0.12 & 0.02 & 0.13 & -0.61 & -0.49 & 0.81 & 0.12 & -1.92 & 1.26 (I) \\
\hline QH20 & 0.53 & 0.21 & 0.09 & 0.28 & -0.04 & 0.89 & -0.24 & -1.14 & 1.58 (I) \\
\hline QH21 & 0.14 & -0.21 & -0.21 & 0.13 & -0.55 & 0.44 & -0.91 & -0.52 & 1.29 (I) \\
\hline Mean & -0.09 & -0.26 & -0.28 & -0.51 & -0.69 & 0.57 & -0.80 & -0.88 & \\
\hline$E F$ & 1.18 & 1.00 & 0.98 & 0.92 & 0.73 & 1.77 & 0.79 & 0.72 & \\
\hline
\end{tabular}

Yellow was I (moderately polluted; $1 \leq P L I<2$ ). From all sample points, the pollution load indices of QH1 QH3, QH5 QH7, an QH14 QH21 were higher than 1 and less than 2 , belonging to moderately polluted degree, suggesting inputs from anthropogenic sources. The pollution load indices of other sample points was less than 1 (no pollution). Maximum PLI was recorded at the $\mathrm{QH} 20$ area. At this location, $P L I$ was higher than the rest of the sampling locations in the Qinghai section (Table 5). This was attributed to vehicular (boat/steamer) emissions, inflows of QH20 metal works, and commercial activities around the sampling location.

According to Contamination coefficients of heavy metals in surface sediments from the Qinghai section of the Yellow, the average metal contamination coefficients in sediments was in the order of $\mathrm{Cr}>\mathrm{Cu}>\mathrm{Fe}>\mathrm{Mn}>\mathrm{Ni}>\mathrm{Pb}>\mathrm{Zn}>$ $\mathrm{Cd}$. Whichever heavy metal $\mathrm{Zn}$ and $\mathrm{Cd}$ could lead to no pollution, heavy metal $\mathrm{Cr}$ could cause greater pollution.

\section{Conclusions}

The total concentrations showed wide variations with $\mathrm{Cu} 11.86 \sim 57.02 \mathrm{mg} / \mathrm{kg}, \mathrm{Fe} 17236.67 \sim 41340.00 \mathrm{mg} / \mathrm{kg}$, Mn $431.93 \sim 877.27 \mathrm{mg} / \mathrm{kg}$, Ni $14.58 \sim 86.11 \mathrm{mg} / \mathrm{kg}, \mathrm{Zn}$ $67.18 \sim 149.00 \mathrm{mg} / \mathrm{kg}, \quad \mathrm{Cr} 87.84 \sim 169.70 \mathrm{mg} / \mathrm{kg}, \mathrm{Pb}$ $1.21 \sim 20.69 \mathrm{mg} / \mathrm{kg}$, and $\mathrm{Cd} 0.27 \sim 1.43 \mathrm{mg} / \mathrm{kg}$ in the sediments from the Qinghai section of the Yellow. The mean values of the heavy metal contents in sediments were arranged in the following decreasing order: $\mathrm{Fe}>\mathrm{Mn}>\mathrm{Cr}>\mathrm{Zn}>\mathrm{Ni}>\mathrm{Cu}>\mathrm{Pb}>\mathrm{Cd}$. The mean values of all the heavy metal concentrations besides $\mathrm{Zn}$ and $\mathrm{Cd}$ in sediments were higher than background value. The sediments had been unpolluted or slightly polluted by $\mathrm{Zn}$ and $\mathrm{Cd}$, and then were seriously polluted by $\mathrm{Cu}$ and $\mathrm{Cr}$.

The correlation between $\mathrm{Cu}, \mathrm{Fe}$, and $\mathrm{Zn}$ concentrations was significantly positive, suggesting that these heavy metals had common sources, mutual dependence, and identical 
behavior during transport. They were mainly of natural origin due to weathering and erosion. The absence of strong correlation among other metals indicated that they might have different anthropogenic as well as natural sources, and that their behavior during transport could be varied.

PCA extracted three components with eigenvalues explaining $76.259 \%$ of the total variance. The first component accounted for $39.98 \%$ of the total variance with high positive loadings of $\mathrm{Fe}, \mathrm{Mn}, \mathrm{Zn}$, and $\mathrm{Cr}$. Their combination in this component suggested a natural origin of these elements. Component 2 accounted for $20.46 \%$ of the total variance for $\mathrm{Cu}, \mathrm{Ni}$, and $\mathrm{Cd}$. Which suggested that these meals could originate from anthropogenic sources.

The calculated results of $I_{g e o}$ indicate that only $\mathrm{Cr}$ could be considered unpolluted to moderately polluted at all stations. All other metals showed an unpolluted situation for other stations $\left(I_{g e o}<0\right)$. This was on the basis of the mean $I_{g e o}$ values of metals in the following order: $\mathrm{Cr}>\mathrm{Cu}>\mathrm{Fe}>\mathrm{Mn}>\mathrm{Ni}>\mathrm{Zn}>\mathrm{Pb}>\mathrm{Cd}$. The average metal $E F$ in sediments was in the order of $\mathrm{Cr}>\mathrm{Cu}>\mathrm{Fe}>\mathrm{Mn}>\mathrm{Ni}>\mathrm{Pb}>\mathrm{Zn}>$ $\mathrm{Cd}$. Average $E F$ of $\mathrm{Zn}, \mathrm{Pb}$, and $\mathrm{Cd}$ showed background levels. Average $E F$ of $\mathrm{Fe}, \mathrm{Mn}$, and Ni had a value close to 1, which could indicate some crustal origin for these metals. The average $E F$ of $\mathrm{Cu}$ and $\mathrm{Cr}$ were much higher, which belonged to slightly polluted, the results indicating a metal source other than lithogenic debris. Maximum PLI was recorded at the QH20 site. The average metal contamination coefficients in sediments was in the order of $\mathrm{Cr}>\mathrm{Cu}>\mathrm{Fe}>\mathrm{Mn}>\mathrm{Ni}>\mathrm{Pb}>\mathrm{Zn}>\mathrm{Cd}$. $\mathrm{Zn}$ and $\mathrm{Cd}$ could lead to no pollution, while heavy metal $\mathrm{Cr}$ could cause greater pollution. In total, the pollution class from the Qinghai section of Yellow was $0-1$, belonging to an unpolluted to moderately polluted degree.

\section{Acknowledgements}

This work was supported by the Program for Changjiang Scholars and Innovative Research Team in University (IRT0966).

\section{References}

1. DEVAI I., DELAUNE R.D., DEVAI G., ARADI C., GORI S., NAGY A.S., TALAS Z. Characterization of mercury and other heavy metals in sediment of an ecological important backwater area of River Tisza (Hungary). J. Environ. Sci. Heal. A 42, 859, 2007.

2. MAO L.J., MO D.W., GUO Y.Y., FU Q., YANG J.H., JIA Y.F. Multivariate analysis of heavy metals in surface sediments from lower reaches of the Xiangjiang River, southern China. Environmental Earth Science 69, 765, 2013.

3. LIU J.J., LIU Y. Study on heavy metal sand ecological risk assessment from Gansu, Ningxia and Inner Mongolia sections of the Yellow, China. Spectrosc. Spect. Anal., 33, (12), 3249, 2013.

4. NIU H.Y., DENG W.J., WU Q.H., CHEN X.G. Potential toxic risk of heavy metals from sediment of the Pearl River in south China. J. Environ. Sci. 21, 1053, 2009.
5. SHEYKHI V., MOORE F. Evaluation of potentially toxic metals pollution in the sediments of the Kor river, southwest Iran. Environ. Monit. Assess. 185, 3219, 2013.

6. DAVUTLUOGLU O.I., SECKIN G., ERSU C.B., YILMAZ T., SARI B. Assessment of metal pollution in water and surface sediments of the Seyhan River, Turkey, using different indexes. Clean-Soil, Air, Water 39, (2), 185, 2011.

7. MOHIUDDIN K.M., OGAWA Y., ZAKIR H.M., OTOMO K., SHIKAZONO N. Heavy metals contamination in water and sediments of polluted urban rivers in developing country. Int. J. Environ. Sci. Tech. 8, (4), 723, 2011.

8. ADEKOYA J.A., WILLIAMS A.B., AYEJUYO O.O. Distribution of heavy metals in sediments of Igbede, Ojo and Ojora rivers of Lagos, Nigeria. Environmentalist 26, 277, 2006.

9. ANITHAMARY I., RAMKUMAR T., VENKATRAMANAN S. Distribution and accumulation of metals in the surface sediments of Coleroon river estuary, East coast of India. B. Environ. Contam. Tox. 88, 413, 2012.

10. CHABUKDHARA M., NEMA A.K. Assessment of heavy metal contamination in Hindon River sediments: A chemometric and geochemical approach. Chemosphere 87, 945, 2012.

11. WANG L., WANG Y.P., ZHANG W.Z., XU C.X., AN Z.Y. Multivariate statistical techniques for evaluating and identifying the environmental significance of heavy metal contamination in sediments of the Yangtze River, China. Environ. Earth. Sci. 71, 1183, 2014.

12. DJORDJEVIC L., ZIVKOVIC N., ZIVKOVIC L., DJORDJEVIC A. Assessment of heavy metals pollution in sediments of the Korbevacka River in Southeastern Serbia. Soil and Sediment Contamination 21, 889, 2012.

13. KRUOPIENE J. Distribution of Heavy Metals in Sediments of the Nemunas River (Lithuania). Pol. J. Environ. Stud. 16, (5), 715, 2007.

14. LONGJIANG M., QIANG F., DUOWEN M., KE H., JIANGHONG Y. Contamination assessment of heavy metal in surface sediments of the Wuding River, northern China. J. Radioanal. Nucl. Ch. 290, 409, 2011.

15. MILENKOVIC N., DAMJANOVIC M., RISTIC M. Study of Heavy Metal Pollution in Sediments from the Iron Gate (Danube River), Serbia and Montenegro. Pol. J. Environ. Stud. 14, (6), 781, 2005.

16. FUJITA M., IDE Y., SATO D., KENCH P.S., KUWAHARA Y., YOKOKO H., KAYANNE H. Heavy metal contamination of coastal lagoon sediments: Fongafale Islet, Funafuti Atoll, Tuvalu. Chemosphere 95, 628, 2014.

17. RAJU K.V., SOMASHEKAR R.K., PRAKASH. Heavy metal status of sediment in river Cauvery, Karnataka. Environ. Monit. Assess. 184, 361, 2012.

18. YAN J.P., HONG H., HE H. Characteristics of Heavy Metals and Their Evaluation in Sediments from Middle and Lower Reaches of the Huaihe River. Journal of China University of Mining \& Technology 17, (3), 414, 2007.

19. FU J., ZHAO C.G., LUO Y.P., LIU C.S., KYZAS G.Z., LUO Y., ZHAO D.Y., AN S.Q., ZHU H.L. Heavy metals in surface sediments of the Jialu River, China: Their relations to environmental factors. J. Hazard. Mater. 270, 102, 2014.

20. GIRI S., SINGH A.K., TEWARY B.K. Source and distribution of metals in bed sediments of Subarnarekha River, India. Environ Earth Sci 70, 3381, 2013.

21. JAYARAJU N., SUNDARA R., REDDY B.C., REDDY K.R. Anthropogenic metal pollution in surface sediments of the Tambaraparni River Estuary. Chemistry and Ecology 27, (4), 337, 2011. 
22. QUINTON J.N., CATT J.A. Enrichment of heavy metals in sediment resulting from soil erosion on agricultural fields. Environ. Sci. Technol. 41, 3495, 2007.

23. SONG Y.X., JI J.F., YANG Z.F. Geochemical behavior assessment and apportionment of heavy metal contaminants in the bottom sediments of lower reach of Changjiang River. Catena 85, 73, 2011.

24. WAKIDA F.T., LARA-RUIZ D., TEMORES-PENA J., RODRIGURZ-VENTURA J.G., DIAZ C., GARCIA-FLORES E. Heavy metals in sediments of the Tecate River, Mexico. Environ Geol 54, 637, 2008.

25. KAUSHIK A., KANSAL A., SANTOSH M., KUMARI S., KAUSHIK C.P. Heavy metals contamination of river Yamuna, Haryana, India: Assessment by metal enrichment factor of the sediments. J. Hazard. Mater. 164, 265, 2009.

26. MULLER G. Index of geo-accumulation in sediments of the Rhine River. Geol. J. 2, (3) 108, 1969.

27. SHAFIE N.A., ARIS A.Z., ZAKARIA M.P., HARIS H., LIM W.Y., ISA N.M. Application of geoaccumulation index and enrichment factors on the assessment of heavy metal pollution in the sediments. J. Environ. Sci. Heal. A 48, 182, 2013.

28. VAROL M. Assessment of heavy metal contamination in sediments of the Tigris River (Turkey) using pollution indices and multivariate statistical techniques. J. Hazard. Mater. 195, 355, 2011.
29. WANG C.C., NIU Z.G., LI Y., SUN J., WANG F. Study on heavy metal concentrations in river sediments through the total amount evaluation method. J Zhejiang Univ-Sci A (Appl Phys \& Eng) 12, (5), 399, 2011.

30. WANG Y.W., YUAN C.G., JIN X.L., JIANG G.B. Application of chemometrics methods for the estimation of heavy metals contamination in river sediments. J. Environ. Sci. 17, (4), 540, 2005.

31. YALCIN M.G., NARIN I., SOYLAK M. Multivariate analysis of heavy metal contents of sediments from Gumusler creek, Nigde, Turkey. Environ. Geol. 54, 1155, 2008.

32. ZHANG W.G., FENG H., CHANG J.N., QU J.G., XIE H.X., YU L.Z. Heavy metal contamination in surface sediments of Yangtze River intertidal zone - An assessment from different indexes. Environ. Pollut. 157, 1533, 2009.

33. YUE X.L., MU X.M., ZHAO G.G., SHAO H.B., GAO P. Dynamic changes of sediment load in the middle reaches of the Yellow basin, China and implications for eco-restoration. Ecol. Eng. 73, 64, 2014.

34. SUN Z.G., MOU X.J., TONG C., WANG C.Y., XIE Z.L., SONG H.L., SUN W.G., LV Y.C. Spatial variations and bioaccumulation of heavy metals in intertidal zone of the Yellow estuary, China. Catena 126, 43, 2015. 